\title{
REFRACTIVE THINKING OF VISUALIZER AND VERBALIZER STUDENTS IN SOLVING GEOMETRY PROBLEMS
}

\author{
Dinda Ayu Fatmalasari \\ Mathematics Education, Faculty of Matematics and Natural Sciences, Universitas Negeri Surabaya \\ e-mail: dindafatmalasari16030174072@mhs.unesa.ac.id \\ Tatag Yuli Eko Siswono \\ Mathematics Education, Faculty of Matematics and Natural Sciences, Universitas Negeri Surabaya \\ e-mail: tatagsiswono@unesa.ac.id
}

\begin{abstract}
Refractive thinking is a person's mental activity in making a decision in solving a problem which is through reflective and critical thinking. Differences in cognitive style in a person affects the differences in refractive thought processes. This is expected to be a liaison for educators to train students by providing varied problems both using pictures and words. This qualitative research aims to describe the stages of refractive thinking of visualizer students and junior verbalizers in solving geometry problems. The method of collecting data through written tests and interviews. Written tests were given to 57 students of 8 th grade students of state junior high schools in Jombang. The research subjects consisted of one student with cognitive style visualizer and one student with verbalizer cognitive style with each subject having high mathematical ability. The results showed that at the identified of problem stage, visualizer students recognized and identified some of the information contained in the problems tended to be faster than verbalizer students. At the strategic stage, visualizer students used image information to found alternative solutions, while verbalizer students used formulas that have been obtained before. This showed that both the visualizer student and the verbalizer student have shown indications of refractive thinking. At the evaluation stage, the student visualizer and verbalizer explained the method used based on logical and appropriate arguments but in the different way.
\end{abstract}

Keywords: Refractive Thinking, Geometry's Problem, Visualizer Cognitive Style, Verbalizer Cognitive Style

\section{INTRODUCTION}

Refractive thinking is the activity of thinking that occurs because of passing through reflective thinking proceeding towards critical thinking which then appears refraction (results). Medeni (2012) also defines refractive thinking as the acquisition of new knowledge that results from reflection and critical thinking. Prayitno (2015) said that refractive thinking will arise when students are given a problem which makes them confused to solve the problem and triggers the emergence of reflective thinking. Pagano and Roselle (2009: 220) revealed that refraction thinking occurs because of the reflection that is signaled by light passing through a medium that triggers critical thinking, so that light coming out of the medium is not the same as reflection. Downey (Pagano and Roselle, 2009) uses the light metaphor to describe the process of refraction that results from reflection towards critical thinking. Refractive is a process in which light (reflection) hits the medium causing a "reaction" to the medium that triggers critical thinking. This refraction process can be seen in Figure 1 by Downey (Pagano and Roselle, 2009) below.

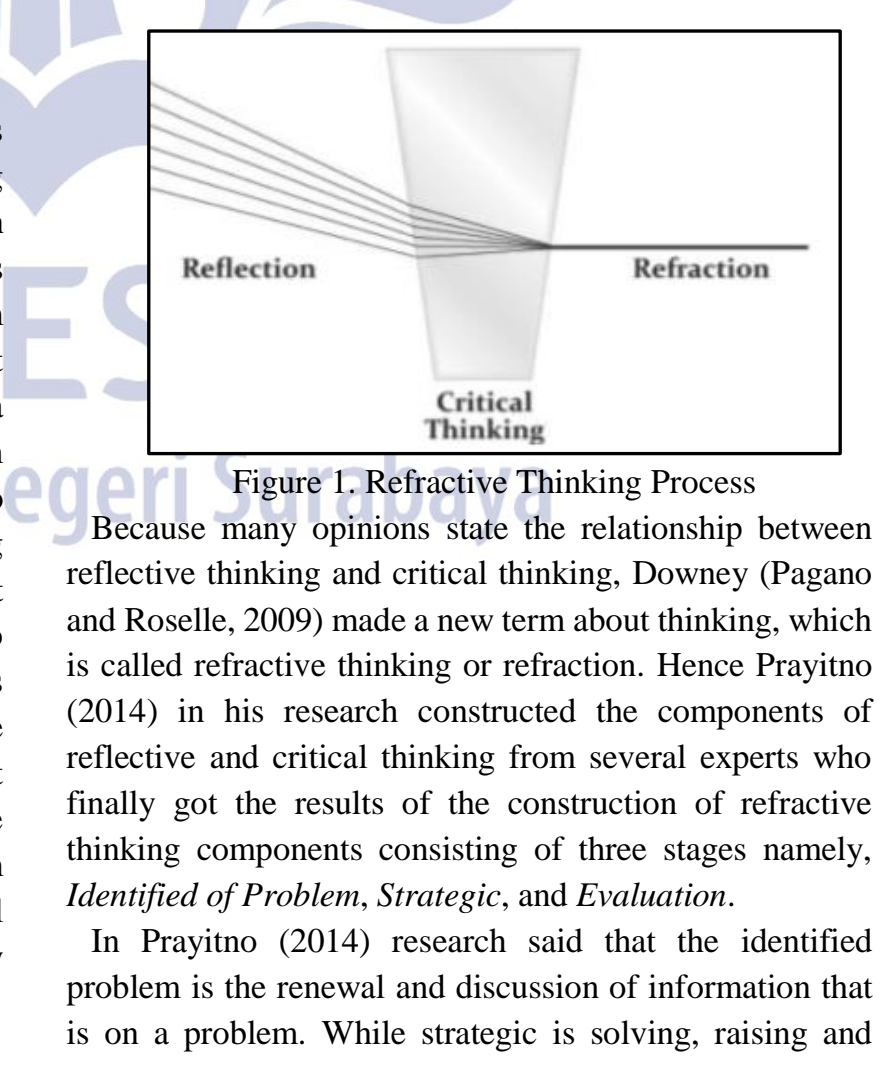


choosing alternative ideas that are used to solve problems. Evaluation is the stage of clarifying the chosen alternative settlement so finding the right answer.

Reflective thinking according to Prayitno (2015) is one of the tools to develop higher-order thinking. While the ability to think at a high level according to Rofiah (Novianti, 2014) is the ability to connect, manipulate, and transform the knowledge and experience already possessed to think critically and creatively as an effort to solve new situations. Geometry problems require that ability to find solutions. The ability to think refractively will arise if someone is confronted with a problem that makes students do reflective thinking and critical thinking in solving the problem. This shows that students who are able to think refractively, also has high mental and intellectual abilities. So the geometry problem may be used to see students' refractive thought processes.

The results of Budiarto's research (Budiarto and Artiono, 2019) stated that in solving geometry problems students were still unable to associate the knowledge already obtained in geometry to solve these problems. This proves that the memory of students regarding the past material is still weak. In addition, the results of the research by Solfitri and Roza (2015) stated that junior high school students still made many mistakes in workmanship procedures and also students did not remember the prerequisite material in solving the problem. The fact is that geometry is one of the material that often appears in national examinations which are too important for students to do exercise in solving problems. In addition, the reason for using this material is because in its completion systematic steps are needed, which enable students to use visual and verbal symbols related to research reviews.

Meanwhile, ideas in mathematics are often conveyed in the form of visual symbols and verbal symbols in which the information is received differently by students depending on their cognitive style. This is reinforced by the opinion of Susan \& Collinson (2005: 65), in which problem solving strategies are influenced by cognitive style. Cognitive style related to differences in the reception of information visually and verbally is cognitive style visualizer and verbalizer.

Someone with a cognitive visualizer style tends to be easier to receive, process, store, and use information in the form of images and graphics. Whereas someone with a cognitive style verbalizer tends to be easier to receive, process, store, and use information in written or text form (Mendelson, 2014). This difference in cognitive style certainly influences the strategy used in solving mathematical problems. Therefore it can be concluded that students who have the same cognitive style are not necessarily the same way to solve mathematical problems.
Especially students who have different cognitive styles, of course, different problem solving strategies.

Prayitno's research (2014) shows that in making decisions on data problems, students go through several stages of refractive thinking which starts with reflective thinking first then continues with critical thinking. In research Maslukha (2018) describes the profile of students 'thinking in solving geometry problems in terms of students' mathematical abilities which in previous studies have not been shown in detail how students choose alternative solutions to other solutions. So this research will discuss about it using different reviews and material. This study aims to describe the stages of refractive thinking of visualizer students and junior verbalizers in solving geometry problems.

\section{METHODS}

This qualitative research aims to describe the stages of refractive thinking of visualizer and verbalizers students in solving geometry problems. According to Bogdan \& Taylor (in Siswono, 2010) qualitative research is a research procedure that produces descriptive data, namely speech or writing and behavior that can be observed by people (the subject) itself. This study uses a cognitive style questionnaire instrument adapted from Mendelson (2014) entitled Visualizer and Verbalizer Question (VVQ), a geometric problem solving test for material relationships between angles of class VII, and interview guidelines in which problem solving tests and interview guidelines are made based on indicators refractive thinking with already validated from one of the mathematics lecturers. The data obtained in this study are the results of the cognitive visualizer and verbalizer style questionnaire, the results of the geometry problem solving test and the results of the interview. This research was conducted in one of the state junior high schools in Jombang with 57 students. Students are given a cognitive style questionnaire which then from the results of the questionnaire students are grouped into students with cognitive style visualizers and students with verbalizer cognitive styles. Then students are given a geometry problem solving test in which the results of the test are analyzed based on indicators of refractive thinking in order to obtain the desired subject, namely one student in each category of cognitive style and also the consideration of a mathematics teacher where the subject is a student who is competent in communication and mathematical ability. Then conducted interviews with selected subjects with the aim to explore information that has not been revealed in the written test.

Table 1. Refractive Thinking Indicators 


\begin{tabular}{|c|c|c|}
\hline $\begin{array}{c}\text { Components } \\
\text { of Refractive } \\
\text { Thinking } \\
\end{array}$ & Code & Indicators \\
\hline \multirow[t]{2}{*}{$\begin{array}{c}\text { Identified of } \\
\text { problem }\end{array}$} & $\mathrm{I}-1$ & $\begin{array}{l}\text { Students are able to identify } \\
\text { information from problems to } \\
\text { be solved }\end{array}$ \\
\hline & $\mathrm{I}-2$ & $\begin{array}{l}\text { Students are able to recognize } \\
\text { the purpose of the problem } \\
\text { based on memory or } \\
\text { experience }\end{array}$ \\
\hline \multirow[t]{3}{*}{ Strategic } & S-1 & $\begin{array}{l}\text { Students are able to integrate } \\
\text { some information so that it } \\
\text { can be used to solve problems }\end{array}$ \\
\hline & S-2 & $\begin{array}{l}\text { Students are able to come up } \\
\text { with several possible ways of } \\
\text { solving problems }\end{array}$ \\
\hline & S-3 & $\begin{array}{l}\text { Students are able to choose } \\
\text { ideas from several ways of } \\
\text { solving problems to be } \\
\text { supported by some of the } \\
\text { arguments of the knowledge } \\
\text { they already have }\end{array}$ \\
\hline \multirow[t]{3}{*}{ Evaluation } & E-1 & $\begin{array}{l}\text { Students are able to solve } \\
\text { problems by choosing } \\
\text { solutions }\end{array}$ \\
\hline & E-2 & $\begin{array}{l}\text { Students re-check the } \\
\text { answers already obtained in } \\
\text { accordance with the intent of } \\
\text { the problem given. }\end{array}$ \\
\hline & E-3 & $\begin{array}{l}\text { Students are able to explain } \\
\text { back the information obtained } \\
\text { valid }\end{array}$ \\
\hline
\end{tabular}

There are three data analysis in this research, namely data analysis of cognitive style questionnaire results, data analysis of problem solving test results, and data analysis of interview results. Data analysis of cognitive style questionnaire results based on VVQ adapted from Mendelson (2014). While the analysis of the geometry problem solving test results is based on the refractive thinking indicator in table 1 , which is a modification of the refractive thinking component made by Prayitno (2014). Data analysis of interview results based on refractive thinking indicators of table 1 through the stages of data reduction, data presentation, and drawing conclusions (Miles \& Huberman, 2014). The following are the problems used in this study.

1. Pay attention to the picture below!

How the large of angle $p$ if known information like in the picture? Explain.

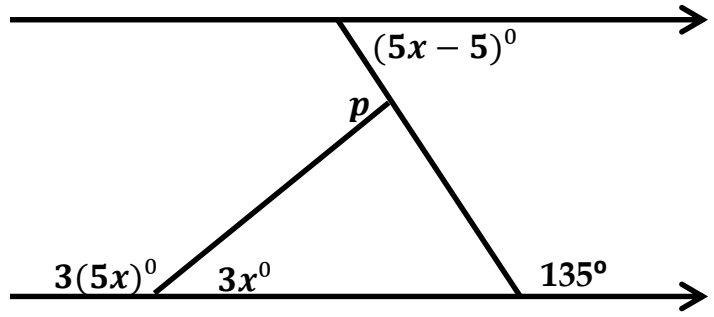

2. Pay attention to the picture below!

How the large of angle $p$ if known information like in the picture? Explain.

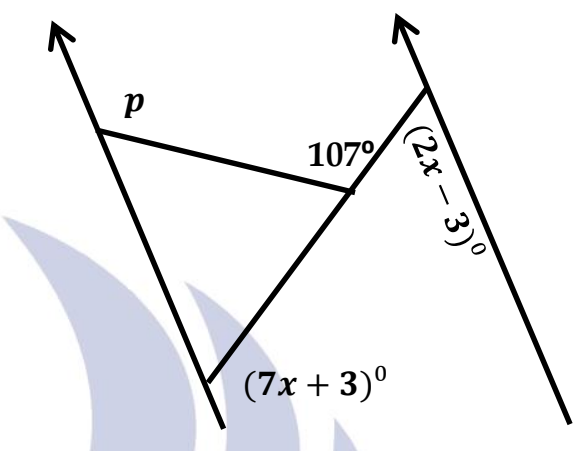

\section{RESULTS AND DISCUSSION}

Based on the data analysis of geometry problem solving test results and subject interviews with the cognitive visualizer and verbalizer style, it is obtained a description of the stages of junior high school students' refractive thinking in solying geometry problems in terms of the cognitive visualizer and verbalizer style as follows.

1. Visualizer Subject

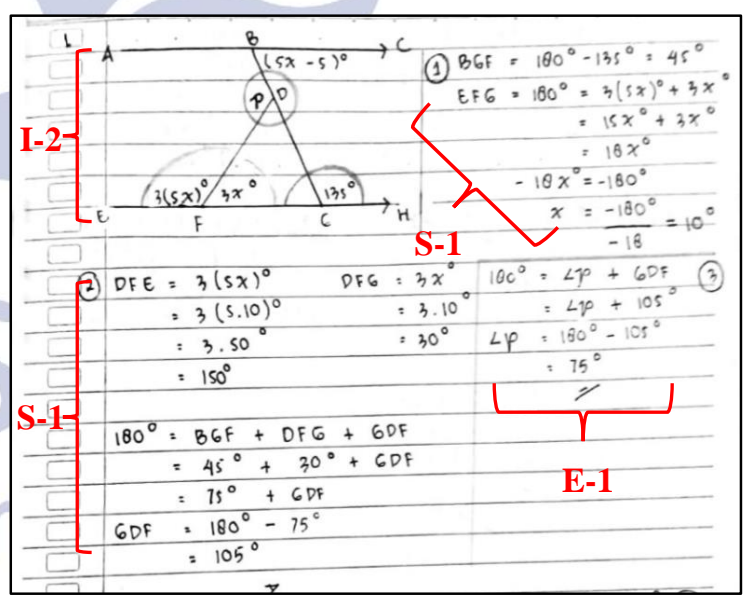

Figure 2. Written Test Results for Students with Cognitive Style Visualizer Problem Number 1

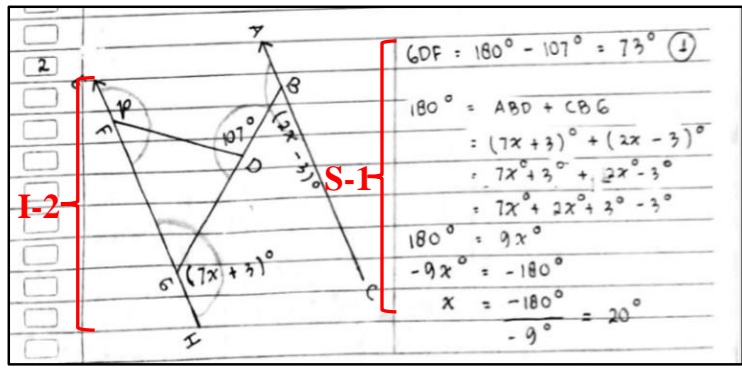




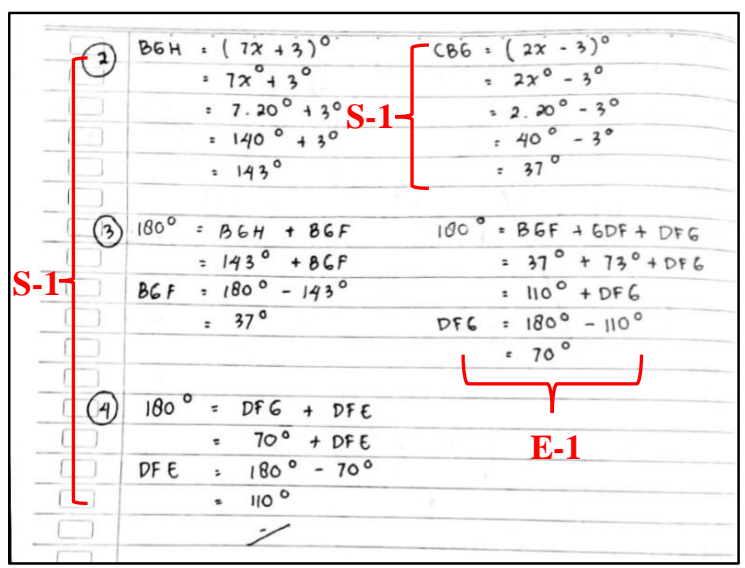

Figure 3. Written Test Results for Students with Cognitive Style Visualizer Problem Number 2

The following interview excerpt shows the subject's arguments regarding the way understands the problem.

Researcher : Do you understand with the problems?

VS Subject : Yes, Miss. Ido.

Researcher : Please explain what is the purpose of the problems.

VS Subject So the two problems given are both using pictures, hence both of them, if I'm not mistaken, are material relations between angles, Miss. I once worked on that problem in 7 th grade. Initially I first observed the drawing, oh yes, understand if told to look for the value of the angle $p$. And in that problem we know the angles that can be used to find the angle value $p$. At first I was confused, because the angles that were known did not use numbers but there was an $x$ variable.

Based on the analysis of test and interview results, the subject with the visualizer's cognitive style when identified from the problem is solved through a picture with one look (I-2). This is in line to Mendelson (2014) which says that visualizers are easier to receive, process, store, and use information in the form of images or graphics. In addition, the subject also discusses some information relating to adding a few scribbles to the problem used to show the relationship between angles that he had previously obtained (I-1). The subject tried to gather some information such as the relationship between the angle $p$ with other angles understood in the problem, but it was not discussed systematically on the question sheet.

The following interview excerpt shows the subject's arguments regarding how subject found alternative solutions.

Researcher : Then why did you choose this method?

VS Subject : I looked at the picture, then I remembered that the known angles were opposite and inner angles. Then I use that method to find the value of $p$.

\section{Researcher : Is there another way?}

VS Subject : It seems like can using the help lines too. So draw another line in the middle of the angle $p$ parallel to 2 parallel lines that are known that, Miss. But I just thought when I was in the middle of working on it. I think later the results will be the same so I just continue to use the initial method.

At the strategic stage after the subject identified a problem, the subject then integrates some information such as the value of the angles associated with the angle sought so that the subject can use it to solve problems (S-1). The subject also explained his argument in choosing a way with a description of other ways that could be used before the subject finally found a way that according to it based on experience and material that had been obtained before (S-2, S-3). Another illustration of the method shown by the subject is to use the help line method which can also be used to solve problems. Because the subject was limited in experience so the subject choose a method with the rules of the triangular corners that were felt to be easier. This is supported by Prayitno (2014) research which in solving data problems, students gather some information to finally got a solution that student thinks was correct. So that it can be said that at this stage the subject is at the stage of refractive thinking.

The following interview excerpt shows the subject's arguments regarding the way subject found the results wrote and statement in re-examining the answers. 
Researcher : how did you do it using the way you've been choose? Number 1, please explain.

VS Subject : I looked for the value of $x$ first Miss, using EFG straight angle. The EFG is 180 degrees, so I add up the EFD angle and the GFD angle is 180 degrees. Find the value of $x 10$. After that I look for the angles of the $C D F$ triangle to get the GDF angle value. The problem is that the GDF angle is aligned with the angle $p$. After finding the GDF angle I can find an angle of 75 degrees, Miss.

Researcher : Already sure with your answer?

VS Subject : InshaAllah Miss, I've been checked several times too.

At the evaluation stage, the subject resolves the problem in the way that subject has chosen using the relationship between the angle of the triangle and the angle of alignment (E-1). The subject also examined the answers several times before the subject was finally convinced of the answers obtained (E-2) and explained the stages of solving the problem relevant to what was written on the answer sheet (E-3).

\section{Verbalizer Subject}

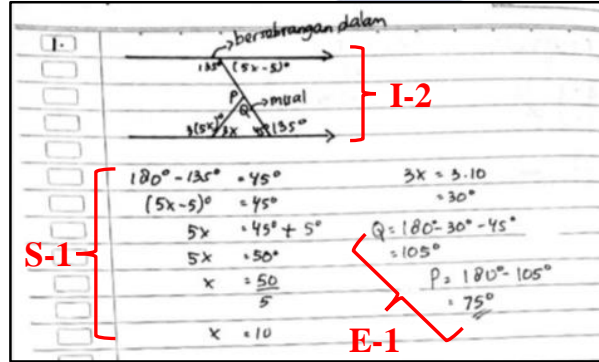

Figure 4. Written Test Results of Students with Verbalizer Cognitive Style Problem Number 1

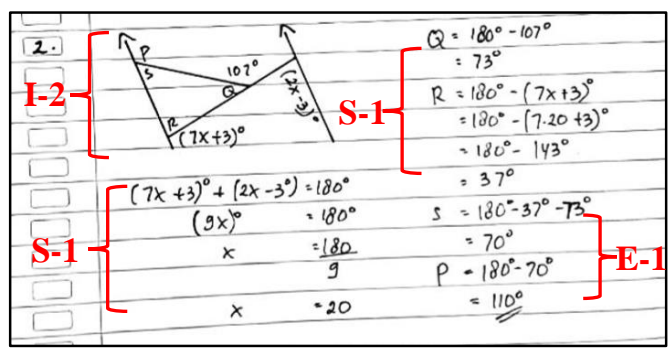

Figure 5. Written Test Results of Students with Verbalizer Cognitive Style Problem Number 2

The following interview excerpt shows the subject's arguments regarding the way the subject understands the problem.

Researcher : Do you understand with the problems?

VB Subject : Yes, Miss. I do.

Researcher : Please explain what is the purpose of the problems.

$V B$ Subject : At first I was confused Miss while I saw the picture. Then finally I understood that it was grade 7 , if I am not mistaken it was opposite corners. it's just that the known angles are not numbers, but there are also $x$ variables.

Based on the analysis of test and interview results, the subject with the cognitive style verbalizer at the identified of problem stage, recognizes the problem through the pictures in the questions (I-2). But it takes several times for the subject to see the picture given before the subject finally understands the meaning of the problem. This is in line with Mendelson (2014) which says that verbalizers tend to more easily process information in written / text form. The subject also identified some known information such as which angles were opposite angles in which had been obtained before (I-1). Through the results of the interview, the subject explains the problem being asked by the problem clearly, namely looking for the magnitude of the angle $\mathrm{p}$ where it is relevant to the given problem.

The following interview excerpt shows the subject's arguments regarding how the subject found alternative solutions.

Researcher: Then why did you choose this method?

$V B$ Subject : Because I have to find the angle value of $p$, the angle value of $p$ is aligned with the angle of $q$. While the angle of $q$ is one of the angles of the triangle. So finally I used a method that looked for the corners of the triangle Miss.

Researcher : Is there another way?

VB Subject : Wait a minute Miss, I was working at that time and 
remembered the way that the angle (5x-5) degrees plus the angle of $3 x$ degrees was the result of the angle p Miss. But I forgot that in the beginning I could get a formula like that from where. So I use the way I remember.

At the strategic stage, the subject integrates some of the information that has been obtained so that the subject can use it to solve problems $(\mathrm{S}-1)$. The information written by the verbalizer subject was almost the same as the visualizer subject, both of which were looking for large angles that have a relationship with the angle to be asked. The subject also explained his argument in choosing a way with an illustration of another way, namely using the relationship between opposite angles, which could be used before finally the subject obtained a method that he thought was appropriate based on experience and material that had been obtained before that was using the rules of the number of triangles $(\mathrm{S}-2), \mathrm{S}$ $3)$. In addition, the explanation of the verbalizer subject was more detailed and mentioned many variables rather than leads to the picture. This is in line with the results of Bestiyana's (2018) research which in analyzing and evaluating answers, verbalizer students were more detailed in explaining both verbally and in writing. The alternative settlement chosen by the verbalizer subject was the same as the visualizer subject, which used the rule of the number of angles of a triangle. So that it can be said that at this stage the subject was at the stage of refractive thinking. This is also supported by the subject's arguments in the interview passage where the subject was able to choose a solution idea based on the experience the subject has gained.

The following interview excerpt shows the subject's arguments regarding the way he found the results he wrote and his statement in re-examining his answers.

\begin{tabular}{|c|c|c|}
\hline esearcher & & $\begin{array}{l}\text { how did you do it using the way } \\
\text { you've been choose? Number } \\
\text { 1, please explain. }\end{array}$ \\
\hline VB Subject & . & $\begin{array}{l}\text { Initially I was looking for an } x \\
\text { value of }(5 x \text {-5) equal to } 45.45 \\
\text { was from } 180 \text { minus } 135 \text { Miss. } \\
\text { Then find } x \text { of } 10 . \text { Then I enter } \\
\text { the } x \text { into the corner } 3 x \text {. The } \\
\text { result is } 30 \text {, then this angle }\end{array}$ \\
\hline
\end{tabular}

(pointing to the other angle of the triangle leg) is 45 because it is aligned with an angle of 135 degrees beside it Miss. So for the angle that $q$ remains, $I$ have the number of angles of 30 and 45 degrees to meet 75 degrees and then the number of angles of the triangle is 180 degrees, so that 180 degrees minus 75 degrees, the result of the angle of $q$ is 105 degrees. Because $q$ is aligned with the angle of $p$, the angle of $p$ is 180 degrees minus 105 degrees. The result is an angle of $p$ equal to 75 degrees.

Researcher : Already sure with your answer?

VBSubject : Sure Miss, I have doublechecked before I collect it.

At the evaluation stage, the subject gets the answer correctly, that is the large of $p$ is 75 degrees from the stages of problem solving written on the answer sheet (E-1). The subject also examined the answers several times before finally the subject was sure of the answers obtained and explained the stages of solving the problem clearly and precisely relevant to what was written on the answer sheet (E2-E3). This is in line with Maslukha's (2018) research which says that students checked their answers again to convince themselves with the answers they have obtained from the calculation results. In addition, the explanation of the verbalizer subject mentioned more variables than leads to the picture. This can be seen in the interview passage that explains how the subject found the results written on the answer sheet above.

\section{CONCLUSION AND SUGGESTION}

\section{Conclusion}

Based on the results of data analysis and discussion related to the results of the test stages of students' refractive thinking, so it can be concluded that the stage of refractive thinking of visualizer and verbalizers students of middle school in solving geometry problems is through the stages of identified of problem, strategic and evaluation.

At the identified of problem stage the visualizer students recognized the problem through images quickly. While verbalizer students need several times for it. Both the 
visualizer student and the verbalizer student wrote down some of the information needed to solve the problem even if it was not written systematically. This shows that students already recognized the purpose of the questions given and identify the information obtained.

At the strategic stage the visualizer and verbalizer students have raised more than one way of solving through interview tests which were indicate by refractive thinking. At this stage the visualizer students used the assistance by image information with added lines while the verbalizer students use formulas, rules, which are verbally conveyed by involving or mentioning variables that have been obtained before. But both of them did not try to used the alternative settlement because they were already fixated with the alternative settlement which they thought was correct in accordance with the problem given. In addition, both the visualizer student and the verbalizer student also explained their way of choosing alternative solutions that were used based on logical arguments.

At the evaluation stage the visualizer and verbalizer students solve the problem given using the method they have been chosen and explained it correctly. Students also repeatedly check the answers so that there were no errors and adjusted them to the given problem.

\section{Suggestion}

This research is limited to students' variety in finding alternative solutions. This can be trained by giving varied problems both using pictures and words so that students are expected to be able to find some strategies in solving these problems which will appear some differences in the refractive thinking process. In addition, the problems used in this study have not facilitated the two categories of cognitive styles.

\section{REFERENCES}

Budiarto, Mega Teguh dan Artiono, Rudianto. 2019. Geometri dan Permasalahan Dalam Pembelajarannya (Suatu penelitian Meta Analisis). Jurnal Magister Pendidikan Matematika. Volume 1 Nomor 1: hal 9-18.

Bestiyana, A. 2018. Profil Berpikir Siswa SMP dalam Menyelesaikan Soal Higher Order Thinking Matematik Ditinjau dari Gaya Kognitif VisualizerVerbalizer. Jurnal Ilmiah Pendidikan Matematika. Volume 1 No. 7.

Fisher, Alec. 2001. Critical Thinking: An Introduction I. Cambridge: Press Syndicate.

Kamus Besar Bahasa Indonesia Dalam Jaringan (Online). Yang diakses melalui kbbi.web.id/pikir pada tanggal 25 Maret 2019.
Lampiran Peraturan Menteri Pendidikan dan Kebudayaan Republik Indonesia Nomor 61 Tahun 2014 tentang Kurikulum Tingkat Satuan Pendidikan.

Maslukha, M. 2018. Refractive Thinking Profile In Solving Mathematical Problem Reviewed from Students Math Capability. Journal of Physics: Conferences Series 947 (2017) 012022.

Medeni, Tunc and Medeni, Tolga. 2012. Reflection and Refraction for Knowledge Management Systems. International journal of eBusiness and eGovernment Studies. Vol. 4 (1): hal: 55-64

Mendelson, A. L. 2004. For Whom is a Picture Worth a Thousand Words? Effects Of The Visualizing Cognitive Style And Attention on Processing of News Photos. Philadelpia. Journal of Literacy. Volume 24, No. 1, 85-105.

Prayitno, Anton, dkk. 2014. Proses Berpikir Refraktif Siswa Menyelesaikan Masalah Data Membuat Keputusan. Dalam Prosiding Seminar Nasional TEQIP, 1 Desember 2014. Malang.

Prayitno, Anton, dkk. 2015. Karakterisasi Berpikir Refraktif Mahasiswa Menyelesaikan Matematika tentang Data. Dalam Prosiding Seminar Nasinal Matematika dan Pendidikan Matematika, 25 April 2015. Surabaya.

Prayitno, Anton, dkk. 2016. Refractive Thinking with Dual Strategy in Solving Mathematics Problem. IOSR Journal of Research \& Method in Education (IOSRJRME). Volume 6, PP. 49-56.

Pagano, M., and Roselle. 2009. Beyond Reflection: Refraction and International Experiental Education. Frontiers: The Interdisiplinary Journal of Study Abroad.

Siswono, Tatag Yuli Eko. 2010. Penelitian Pendidikan Matematika. Surabaya: Unesa University Press.

Solfitri, T. dan Roza, Y. 2015. Analisis Kesalahan Dalam Menyelesaikan Soal-Soal Geometri Siswa Kelas IX SMPN Se-Kecamatan Tampan Pekanbaru. Pontianak.

Susan, H dan Collinson, G. 2005. Achieving EvidenceBased Practice: A Handbook for Practitioners, Second Edition. Elsevier. 